\title{
Adaptation of a Teenagers' Personality in the Multicultural Environment of a Children's Social Organization
}

\author{
Alena Martynova \\ Faculty of Pedagogy and Psychology \\ Nizhnevartovsk State University \\ Lenin str. 56, 628605 Nizhnevartovsk \\ Russian Federation \\ e-mail: arina-pirogova@yandex.ru \\ Liliya Ibragimova \\ Faculty of Pedagogy and Psychology \\ Nizhnevartovsk State University \\ Lenin str. 56, 628605 Nizhnevartovsk \\ Russian Federation \\ e-mail: laibra@yandex.ru \\ Elena Bauer \\ Faculty of Pedagogy and Psychology \\ Nizhnevartovsk State University \\ Lenin str. 56, 628605 Nizhnevartovsk \\ Russian Federation \\ e-mail:bauerea@yandex.ru
}

\begin{abstract}
The article theoretically summarizes the problem of formation of a multicultural environment as a condition for the adaptation of a teenager in a children's public organization. In modern education, multiculturalism is an acute issue, which reveals itself in social organizations, too. Children's social movements and organizations, which run educational activities under the guidance of professional teachers, have a positive effect on the personality development and socialization of teenagers. Psychological and pedagogical science has not yet fully described such a complex multifactorial process as a multicultural educational space. This is also relevant for children's social organizations that operate in the multicultural environment and are multicultural themselves. The wide pedagogical and educational sphere, and the sphere of personality development in teenagers, needs research on multiculturalism, and of particular importance are the works devoted to the activities of children's social organizations and the multicultural environment as a form and product of the activities of bearers of different cultures. Researchers have already established that factors aimed at the development of the subject's social activity contribute to the spiritual enrichment of both various microenvironments and the multicultural environment itself. When considering the multicultural environment as a condition for the adaptation of a teenager in a social organization, we analyzed the available works on the problem and found that this phenomenon can be seen a certain form and product of the activities of people of different cultures. Therefore, factors aimed at developing the social activity of a teenager contribute to the spiritual enrichment of both various microenvironments and the multicultural environment itself. The analysis of the modern academic sources and the realities of the pedagogical and sociocultural situation confirm that recently the problems of adaptation of a teenager in a children's public organization have received noticeable attention in educational science. The analysis of the scientific and pedagogical literature on the problem and the study of its real state based on the generalization of the experience of a number of children's social organizations suggest that the multicultural environment is one of the most important conditions for the adaptation of a teenager in a children's social organization.
\end{abstract}

\section{Introduction}

Children's social organization is a voluntary, self-regulating and self-governing association of children and adults, created for joint activities and driven by common goals and interests. Children's social organizations include associations, federations, unions, leagues, foundations, and other organizations. There are international, national, regional and local children's social organizations (Bim-Bad 2002).

Today, children's movements and organizations in Russia run numerous noteworthy activities, events, campaigns, and useful and meaningful initiatives. Children's associations are engaged in charity, organize outdoor activities, compete in intellectual and sports tournaments, and initiate environmental projects. The upbringing of 
young leaders is hardy possible without them as such organizations are uniquely placed to help children socialize, communicate and make friends. Brought up this way, the young generation finds themselves able to create new economic, national, value-laden, and cultural conditions in their community, country, and the world (Bauer et al. 2018).

Children's social organizations vary in form, structure, degree of coordination, goals, content and areas of activity. Managing such an organization often involves taking care of a complex structure, formalizing documents, developing a charter, creating a system of governing bodies, etc. There are also informal organizations that spring up from avocational interests, enthusiasm or entertainment preferences.

The Soviet time decrees that regulated activities of organizations were replaced by governmental acts that support the children's movement in the Russian Federation. The freedom from tight state control facilitated the active development of informal self-regulating organizations. Since the 1990s, various children's associations have been created and legally supported in Russia. In December 2006, the Government of the Russian Federation adopted the Strategy of State Youth Policy. This document pays much attention to children's organizations and supports them.

At the same time, the absence of a unified methodological service, the loss of established systems for training, retraining and advanced training of personnel, and the issues of financial provision point to serious problems in the development of children's movement in Russia. At the federal level, there is no executive body that would unite representatives of the existing organizations.

However, the positive trends in development of some children's organizations and movements suggest that these associations can become a sustainable basis for the formation of fundamental values in the younger generation and develop the unique human qualities in children. Valuable traditions have not been forgotten and bring children together again for good cause. The main task for teachers is to popularize their assossiations and to bring more children to the fold.

At present, Russia has a large number of children's social organizations of various types and forms. By territorial coverage, they can be categorized into national, inter-regional, regional and local. School-based children's organizations, such as student committees, unions, 'republics' and others, are also widespread. In addition, there are sports associations, leisure associations (amateur groups, hobby clubs, etc.), and temporary public associations created to ensure participation in international, federal, regional programs of social and educational purpose. Many children's organizations are members of the National Council of Youth and Children's Associations of Russia that combines the efforts of such associations in Russia, helps them to act on their interests, and protects the rights of youth and children.

\section{Multicultural environments as a condition for formation of fundamental values}

In today's context, the environment of any educational organization is the intersection of interacting subcultures (age-diverse, heterogeneous, originating from different social and ethnical groups, etc.) which are structural units of the culture, and, therefore, it can be considered as multicultural. The concept of 'multicultural environment' can be disclosed through the category of culture. Matsumoto (2003) defines culture as "a dynamic system of rules, explicit and implicit, established by groups in order to ensure their survival, involving attitudes, values, beliefs, norms and behaviors, shared by a group but harbored differently by each specific unit within the group, communicated across generations, relatively stable but with the potential to change across time." A multicultural environment can be seen as a specific form and product of the activities of people of different cultures. Consequently, factors aimed at the development of social activity of a person contribute to the spiritual enrichment of both various microenvironments (environments of the immediate surrounding) and the multicultural environment itself.

The phenomenon of multiculturalism has become the object of research in the USA in the second half of the 20th century. Gordon (1964) defined 'multicultural environment' as the process in which two or more individuals or groups adopt certain patterns of behavior. Exploring the interaction of society and groups of emigrants, the researchers emphasized that the development of American industry and agriculture was based on the contribution of many races and religions.

The cultures of different groups mix and form a new culture, which is somewhat different from the culture of any of these groups taken separately, thus introducing new cultural paradigms into the life of the nation.

The term 'multicultural environment' had not been used yet, and often the concepts of 'education' and 'educational environment' were confused.

Education involves the creation of a special educational environment with various paths for the development of people in this environment. Educational environment is a system of influences and conditions that form a personality according to a given pattern and provide opportunities for personal development.

In Russia, Bondarevskaya (2003), Borisenkov (2006), Gukalenko (2000), and other researchers have studied the multicultural environment since the 1990s-2000s. This is an environment in which students acquire knowledge and, at the same time, accurate facts are communicated while maintaining respect for minority groups. 
Thus, the multicultural environment contributes to the formation of national identity, prepares students for understanding other cultures, and gives conditions for recognition and acceptance of cultural diversity. The goal of education in the multicultural environment is to form a personality that is capable of active and effective living in a multinational community.

The historical conditionality of the multicultural environment suggests a qualitatively different interconnection of its elements in each era. At the present stage of society development, the model, content, and structure of the multicultural environment are so complicated that without analyzing them and studying the mechanisms of their functioning, it is difficult to understand how a personality develops spiritually. The multicultural environment does not cultivate only individuals, but also the society, allowing it to take the best features from each culture.

The concept of 'multicultural educational space' is based on the category of 'culture' and can be interpreted through it. However, the interpretations of the concept of 'culture' vary greatly (there are several hundred different definitions), which causes difficulties in disclosing the concept of 'multicultural education'.

The culture of the 21 st century manifests itself as a world integration process in which different ethnic groups and ethnic cultures mix, while man in the current sociocultural situation lives at the boundary of cultures, the interactions with which require dialogue, understanding, respect for the cultural identity of other people. Given the new sociocultural realities, the educational science has to offer new, appropriate directions for the development of education.

Culture and education are two interconnected processes. Culture has now integrated so much that any educational space is a polylogue of cultures. An educational institution is expected to translate the culture of the society into the culture of a personality. The development of cultures promises a polyphony of cultures, and hence the dialogue of cultures acts as a way of introducing a personality to the values of culture.

Education should shape a personality capable of global thinking in all the multifaceted completeness of intellectual, cultural, psychological and social development. The improvement of education should be based on the formation of a different type of intelligence, thinking, attitude towards the rapidly changing informational realities. The content and methods should be aimed at the formation of rational skills in students, such as to operate information, to master computer technologies and information modeling, and to think professionally and pragmatically (Selivanova 2000).

The report of the UNESCO International Commission on Global Strategies for the Development of Education in the 21st Century emphasizes that education should help ensure that, on the one hand, a person understands their roots and thus can determine their place in the world and, on the other, instill respect to other cultures.

For the multicultural education, both universal values that go beyond group attributes and all the diverse values that determine group membership and create unique cultures and worldviews are important. The origins of universal values are in cultural, religious and national traditions. No matter how different these traditions are, they have generated many similar values shared by different peoples, regardless of the place and time. The multicultural education provides an opportunity to study and understand the diversity of the peoples inhabiting the world. Cultural differences that determine a person's belonging to a particular group are the most obvious manifestation of the diversity of values and points of view.

A multicultural educational space is a spatially marked environment that does not include only the institutions specially created and intended for the upbringing and education of adolescents (universities, schools, etc.), but also other social systems and phenomena, such as people, institutions, objects, social processes, media of mass communication, leading ideas, value orientations, and everything that causes profound changes in a multicultural society (Pilyugina 2016).

The essence of adaptive multicultural educational space follows from the justification of the contradictions between:

- the need to appeal in the multicultural education to the integrity of the culture and the need to reflect its ethnic components that are relevant to the subjects of education;

- the integrity of the cultural environment and the functioning of various ethnic components in it;

- the need to ensure that a personality assimilates a holistic universal human culture and its ethnic content (Gukalenko 2000).

Given the above, a multicultural educational space also acts as a spatially marked multicultural environment in which the need for education, adaptation, protection and support of various ethnic communities and individuals is satisfied based on dialogue, mutual enrichment and interaction of cultures. The purpose of the adaptive educational space is to create the conditions, mechanisms and technologies for the adaptive integration of the personality into the culture through education. These goals are achieved through the recognition of national human culture as a factor in the development of education and the need for its implementation in the context of cultures. 
Obviously, in the multicultural world and multi-ethnic Russian society, the multicultural education is becoming an integral part of the teacher's pedagogical culture. It includes culturological and ethno-historical knowledge, understanding of the importance of cultural pluralism, the ability to highlight and introduce into the general education ideas that reflect the cultural diversity of the world, and the ability to organize the educational process as a dialogue of the bearers of different cultures in time and space.

The modern development of the world and the culture sets new tasks for educational science concerning the study of mental-forming functions in the upbringing, formation and development of a student's personality in the multinational society. Namely, education, being a field of social and cultural life, is interpreted as a comprehensive cultivation of a wholesome and free personality that is able to defend their standpoints and values (Pogrebnaya et al. 2019). One of the strategic directions of education is the transfer from generation to generation and the consolidation in each of them of the most stable, historically accumulated spiritual, ideological and cultural values of the corresponding society, which determine the deep foundations of its specific mentality and reproduction of its spiritual heritage (Mitrofanova and Smirnova 2003).

The legal basis for ethnocultural education with a multiethnic, multicultural composition is the Constitution and the Federal Law on Education in the Russian Federation. The law establishes state educational standards, which include the federal and national-regional components. This enables the subjects of the federation to enrich the educational content with material reflecting the cultural heritage of the people and the religious features in the development of the culture.

It is impossible to form a personality only by school education, and the failure to understand this entails pedagogical isolation, underestimation of the social environment in the upbringing of a person, an illusion that the school is capable of solving the problem of raising the desired personality on its own. This is also impossible because the school does not educate a child 'from scratch', since earlier socialization has already taken place in the family and in the microenvironment of this child.

In the concept of multicultural education, a child and their world appear to be 'culturally mediated'. In other words, subjectivity is not considered as the initial 'natural' property of a human being, but as the result of the complex process of interaction between the individual nature and the sociocultural environment of development and socialization. In this regard, subjectivity cannot act as a universal source of development and educational impact. However, being an object of preliminary study, diagnosis and content of the multicultural education, it should meet the following criteria:

- reflection of humanistic ideas in the educational process;

- characteristics of unique ethnic, national distinctive features in the cultures of the peoples of Russia and the world;

- disclosure of the common features in the cultures of the peoples of Russia and the elements of traditions that allow us to live in peace, harmony, tolerance, and agreement;

- familiarizing members of the organization with the world culture, revealing the process of globalization and the interdependence of countries and peoples in the modern conditions;

- humanism that expresses an unconditional faith in the good in the nature of a child;

- democracy based on the recognition of equal rights and duties for adults and children;

- tolerance to different views, morals, habits, values of various peoples, nations, religions;

- competence, i.e. the need to form the special abilities in adolescents to master knowledge, to educate an intellectual person who is able to solve creative tasks in a multicultural space;

- value-culturological personality-oriented approach as the basic content of multicultural education.

\section{Pedagogical approach in social adaptation}

Let us dwell in more detail on the content of the pedagogical approach that is adequate to the features of social adaptation of a children's social organizations in the multicultural environment.

In our opinion, such a pedagogical approach should use personality-oriented educational technologies that allow naturally combining personality development and activity. The criterion base of personality-oriented learning relies on tracking and evaluating the formed qualities of the mind (intellect) as new personality traits rather than the acquired knowledge and skills.

Some scholars note that, at present, the transition from standard educational technologies to creative, personality-oriented ones has already been outlined, since it is these technologies that affect the internal mechanism of personality development through the use in the educational process of Learning Technologies as an Educational Study, Collective Thinking Technologies, Educational Design Technologies, and Problem-Learning Technologies.

When considering the means of social formation of personality, social pedagogy can offer solutions of social problems using educational approaches, methods and tools. Among these arethe personality-oriented 
approach, the pedagogical stimulation of motivation, a variety of educational tools and methods (persuasion, encouragement, punishment, approval, training, etc.), the content of learning activities (crafts, folk traditions, arts, games, sports). The content of education is an environment in which the formation and development of a child's personality takes place. It is characterized by the humanistic orientation, appeal to the humaneness in a person, humanistic norms and ideals. The technologies of personal orientation are searching for the methods and means of training and education that correspond to the individual characteristics of each child: they adopt methods of psychodiagnostics, change the organization of children's activities, remedy the relationships between the children, use a variety of teaching aids, and reconstruct the content of education. The personality-oriented approach is opposed to the authoritarian, impersonal and soulless approach to the child. The atmosphere of love, care, and cooperation creates the conditions for creativity and self-actualization of the personality (Yakimanskaya 1996).

It is advisable, along with the existing areas of psychological and pedagogical practice such as pedagogical education and subject teaching, to highlight a new direction - social learning. The relevance of this direction is due, first of all, to the extremely undeveloped social skills of today's teenagers. Their typical problems are the inability to engage in constructive social contact, establish a flexible dialogue with peers and adults, determine their personal position in society and, in particular, in a group, and the lack of basic self-regulation, while all this gives way to inadequate protective reactions to social situations. These problems are aggravated when teenagers enter a new social environment. Thus, a teenager needs 'social literacy' in addition to 'scientific literacy' and, as per the topic of this research, they can obtain it a children's social organization.

Social learning is the formation of skills of constructive interaction with people at the interpersonal and social levels, aimed at achieving a variety of socially significant goals. In its subject and methods, it is one of the types of psychological assistance. To teach, in the social sense, is to help a person become a mature individual capable of having a successful live in the society.

A particular task of social learning is to teach social interaction as organizing a person's mastery of the means of communication with other people.

The purpose of social learning is to create favorable conditions for a person to acquire the qualities of subjectivity, i.e. independence, activity, and responsibility in the broadest sense of the word.

A socially learned person masters the art of living in society and creating social relations on the basis of their unique personal potential. The concept of 'subjectivity' of personality reflects the ability to independently create the life path and to engage in all kinds of specific human activity, may it be creative, free, and moral.

In social learning, there are three main areas of development of subjectivity:

- reflexive - awareness of the positive image of the Self and one's social position. Personal reflection is a form of self-regulation at the highest value-semantic level personality development;

- behavioral - expanding the arsenal of practical skills to live in harmony with other people;

- $\quad$ activity-related - creation of material and spiritual values.

A teenager must learn the following skills:

- build up life values and achieve concrete practical results;

- distinguish between 'goals - results' and 'intermediate goals - means';

- understand and correlate wishes and opportunities with social requirements;

- understand the nature of social relationships and behavior;

- possess a wide repertoire of behavioral skills in various areas of communication, such as intellectual, labor, leisure, inter-gender and other types of communication.

The main content of social learning is the creation of favorable conditions for proactive personal selfdetermination.

The following features of social learning can be distinguished:

- $\quad$ social learning is more pronounced didactic in nature. It is built on the clear organization of educational activities in space and in time and is aimed at specific practical results of the students' joint activities, correlated with their natural life activities;

- social learning is carried out in the framework of a specially created society that is distinguished by every teenager.

A developing social environment (in our case, a children's public organization) is a society that differs from the usual social environment in higher content and intensity of the joint activity and communication and in an emotionally and intellectually rich atmosphere of cooperation and creation. 
In such an environment, both interpersonal and group mechanisms for the successful self-development of an individual are most fully actualized.

The role of educators can be narrowed down to setting up 'the rules of the game'. The educational effect is ensured primarily due to the social activity of the students themselves. The construction of a developing social environment as a basic principle of social learning provides an impressive impact.

The following technologies are rather universal in terms of the possibility of application in various organizational conditions for working with teenagers. These technologies are based on several mechanisms that create a developing social environment:

1. Formation of the spiritual culture of adolescent society.

The main conditions for the formation of motivation are the joint experiencing of the sense of belonging to a special teenage subculture that combines romanticism and high social activity; the sense of belonging to a prestigious public organization; introduction to high life goals and values. For many teenagers, discussing the issues of personal self-determination and the meaning of life in a circle of peers is the first, and sometimes rare, opportunity to recognize their Self and their potential.

2. Functional inclusion of adolescents in a joint activity.

The educators act as a 'collective of creators', operating in accordance with the organizational order, rituals and paraphernalia adopted by the children's social organization, rather than as a 'group of like-minded colleagues' in a declarative form. For example, the educators form their own squad and, along with other squads, participate in assemblies and competitions.

3. Inclusion of participants in a highly organized community.

The level of organization of the developing social environment (a children's social association) stands in a rather sharp contrast with the usual living environment. The organizational standards, structure, and processes are clear and orderly. The collective actions happen at a fast, consistent pace. A high degree of involvement of individuals in joint activities is typical.

4. Democratic introduction of organizational order in a children's social organization.

Organizational standards and structure are presented at the beginning of the school year as long-standing traditions, created by the members of the organization themselves, rather than as 'directives of the pedagogical council'. Thus, the possibility and necessity of the participation of children in the ongoing creative process is emphasized.

5. General spatial organization of collective actions.

Team building, sports competitions, arts, dancing and other group events are performed in the 'visibility zone' for each member of the children's social organization. Children perceive themselves and each other through the prism of collective activity, which stimulates the maturation of genuine sociality in the personality.

6. Social, spiritual and substantive enrichment of activity.

Highly informative, both socially and spiritually, and substantively diverse activities are a system-forming factor in the developing social environment, determining its orientation and originality. The members of the organization participate in group discussions on social and personally significant topics, prepare theatrical performances, compete in sports and intellectual competitions, and take part in song and dance festivals.

A special place belongs labor activity, such as assistance in the restoration and maintenance of historical monuments, participation in environmental activities, assistance to the elderly and disabled, and self-care work. The daily curriculum includes training aimed at acquiring social skills (methods of effective communication, methods of emotional self-regulation).

7. Intensification of intellectual, emotional and behavioral components in joint activities.

Collective actions are performed on verbal (chanting slogans, greetings, singing songs) and sensory (games, marches, dances) levels. Events take place at a fast pace. Time and material resources for their preparation are quite limited. The public presentation of the results increases the responsibility and emotional feedback of the participants. Most events take place in the form of competitions. The emotional saturation, the need to speed up intellectual and creative efforts, high energy costs altogether ensure the maximum involvement of each member of the children's social organization in joint activities, eliminate the risk of useless 'hanging out' and create the effect of a large productive life.

Such educational strategies provide a high level of motivation for achieving success and revealing the creative potential of teenagers and provide room for positive self-affirmation of the students.

The 'social oasis' is a relatively autonomous system, but due to good organization it is able to smooth out external destructive influences, direct them in a positive direction, and in the same way, its ability of influencing a person is remarkable.

The studies of the value-related problems and attitudes in adolescents (Dubrovina 1989) show that a number of adolescents reject the very prospect of living a full life in a socially enriched environment as the conservative attachment to the usual ways and place of life is too strong and the prevailing, albeit imperfect, mode of existence is seen a satisfactory. Such teenagers is quite happy 'here and now' even in problematic socio-economic situations.

To a large extent, this attitude is typical of adolescents having a retardation in personal development, especially in the sphere of meaning-forming qualities, such as values, goals, content and meaning of life. If such 
teenagers by chance find in a developing environment ('social oasis'), they experience psychological discomfort and difficulties with adaptation to the new environment, and at first show a desire to return to habitual conditions.

However, the problem of motivating for willingness and the ability to stay in a 'social oasis' is relevant for adolescents. The will to join 'social oases' and to promote their expansion in society is inherent in those adolescents who have a more developed social "self":

- a combination of the need for self-development with the need to contribute to the development of other people;

- a sufficiently pronounced complex of meaning-forming personality traits (value guidelines, goals, responsibility, freedom of choice, etc.);

- developed differentiation of personality problems and ways to solve them.

The organization of joint activities of the most advanced in personal development adolescents with ordinary peers can ensure the formation of social unity and exclude social selection. Ibragimova (2002) notes that it is advisable to involve students in multidimensional, personally and socially significant educational and extracurricular activities organized in the form of a multi-ethnic community of children, in order to harmonize interethnic relations, create normal socio-ethnic, psychological atmosphere in educational institutions, and form humanistic ethno-cultural ties. To do this, educators may:

- celebrate national holidays associated with traditional labor;

- organize games and exhibitions on national culture, sports competitions in national sports:

- organize cooking competitions, tastings of national dishes and other events with ethnocultural content that is meaningful to the children in the team.

\section{Conclusions}

Having analyzed the theoretical and empirical material on the studied problem, we can list the following features of the pedagogical approach to the content and organization of social adaptation of teenagers in a multicultural environment in a children's social organization:

- personality-oriented education;

- psychologization of the educational process, its comprehensive socio-psychological-pedagogical support, which allows studying and taking into account the personality characteristics of a teenager that originate from both their personal qualities and the surrounding multicultural environment of the educational institution;

- use of social learning in the educational process;

- inclusion of the members of a children's social organization into multifaceted, personally and socially significant activities;

- pedagogization of the multicultural educational environment of the children's social organization;

- ability to apply new information in practice since it is often difficult to navigate a large number of diverse information flows (Ibragimova and Scobeleva 2018).

\section{References}

Bauer E, Salavatova A, Shikhaliyev R (2018) The educational environment of the university as a means of preventing the ideology of extremism among young people. Advances in Social Science, Education and Humanities Research 288: 216-219.

Bim-Bad BM, Pedagogicheskiy enciklopedicheskiy slovar, $1^{\text {st }}$ edn. (Pedagogika: Moscow 2002), pp. 64-65

Bondarevskaya EV (2003) Lichnostno-orientirovanny podhod kak tekhnologiya modernizacii obrazovaniya. Metodist 2: 2-6.

Borisenkov VP, Polikulturnoye obrazovatelnoye prostranstvo Rossii: istoriya, teoriya, osnovy proyektirovaniya, $2^{\text {nd }}$ edn. (Pedagogika: Moscow, 2006), 458 p.

Dubrovina NV, Formirovaniye lichnosti starsheklassnikov, $1^{\text {st }}$ edn. (Pedagogika: Moscow, 1989), 168 p.

Gordon MM, Assimilation in American Life: The Role of Race, Religion, and National Origins, $1^{\text {st }}$ edn. (USA, 1964), $287 \mathrm{p}$. 
Gukalenko OV, Polikulturnoye obrazovatelnoye prostranstvo kak sreda podderzhki I zaschity lichnosti uchaschegosya, $1^{\text {st }}$ edn. (Tiraspol, 2000), 83 p.

Ibragimova L, Scobeleva I (2018) Conditions for creation and development of media culture in students of secondary professional education. Secondary education 1: 89-94.

Ibragimova LA, Cennostnye orientacii uchaschihsya v sisteme polikulturnogo obrazovaniya: istoriya, razvitiye, perspektivy. Monografiya, $1^{\text {st }}$ edn. (RIC Alpha: Moscow, 2002), 175 p.

Matsumoto D, Psychology and Culture, $1^{\text {st }}$ edn. (Moscow, 2003), 346 p.

Mitrofanova SV, Smirnova EV, Multicultural Educational Space, $1^{\text {st }}$ edn. (Stavropol State University: Stavropol, 2003), 88 p.

Pilyugina EI (2016) The multicultural environment of the university as a condition for the formation of self-esteem of migrant students during the period of socio-psychological adaptation. Young Scientist 5 (1): 4-6.

Pogrebnaya IA, Mikhailova SV, Ibragimova LA (2019) Formation of readiness and motivation of students for independent work in higher technical educational institution. Amazonia Investiga 8 (21): 483-490.

Selivanova PL, Educational Space as An Object of Pedagogical Research, $1^{\text {st }}$ edn. (Institute for Advancement of Teachers: Kaluga, 2000), 248 p.

Yakimanskaya IS, Person-Oriented Education In a Modern School, $1^{\text {st }}$ edn. (Sentyabr: Moscow, 1996), 39 p. 